\author{
Research Article \\ www.ijrap.net (ISSN:2229-3566)
}

\title{
A CLINICAL EVALUATION OF KADAMBA (ANTHOCEPHALUS INDICUS) ON RESPIRATORY SYSTEM UNDER SPINAL ANESTHESIA
}

Vimal Kumar $^{1 *}$, Namrata Kulshrestha ${ }^{2}$, K.K. Pandey ${ }^{3}$

${ }^{1}$ Assistant Professor, Department of Shalya Tantra, Rishikul Ayurveda P.G. College and Hospital, Uttarakhand Ayurveda University, Haridwar, Uttarakhand, India

${ }^{2}$ Lecturer, Department of Shalya Tantra, SKD Government Ayurvedic College and Hospital, Muzaffarnagar, Uttar Pradesh, India

${ }^{3}$ Professor and Head, Department of Sangyaharan, Faculty of Ayurveda, Institute of Medical Sciences, Banaras Hindu University, Varanasi, Uttar Pradesh, India

Received on: 06/01/20 Accepted on: 24/02/20

\author{
*Corresponding author \\ E-mail: imsvimal@gmail.com
}

DOI: $10.7897 / 2277-4343.110227$

\begin{abstract}
Kadamba is described in Vednasthapana Mahakasaya in Charaka Samhita, so this study was to evaluate the efficacy of Kadamba ${ }^{2}$ as analgesic and antiinflammatory in Shalya Tantra department, Faculty of Ayurveda, IMS, BHU, Varanasi. This research work was done on 40 healthy patients. Which were divided into two groups included 20 patients with same age, height, and weight distribution. The patients were posted for lower abdominal surgeries and anorectal surgeries. Group I was pre medicated with kadamba ghanvati $1 \mathrm{gm}$ ( 2 tablets) at 10 pm preoperative night and 90 min. before anesthesia and group II was pre medicated with tab. diclofenac sodium $50 \mathrm{mg}$ at $10 \mathrm{pm}$ preoperative night and 90 min. before anesthesia. It was observed that no alteration in respiration, mean blood pressure, pulse rate, oxygen saturation etc. and no post anesthesia sequels were observed. It shows that trial drug doesn't have side effects.
\end{abstract}

Keyword: Anesthesia, LSAB, MAP Kadamba, Premedication, Ghanstava.

\section{INTRODUCTION}

Sangyaharan $^{1-3}$ (Anesthesiology), the science based on the knowledge of Pharmacology, Biochemistry, Physiology, Biotechnology and Medicine and lastly the surgery. It is a science of natural phenomena, dealing with measurable, predictable and therefore, reproducible effect of drug on the function of cellular structure of animal and human.

A large number of indigenous drugs mentioned in Ayurvedic literature were experimentally screened on the animals and also studied clinically on the patients as pre anesthetic medicant ${ }^{4}$ drug such as Brahmi, Jatamansi, Mandukparni, Shigru and Dashmool etc. The encouraging results of their studies prompted us to work on this line and a well-known Vednasthapaka ${ }^{1}$ drug; Kadamba (Anthocephalus indicus) was selected to evaluate its analgesic and anti-inflammatory activity in practice of Sangyaharan as premedicate. The trial drug Kadamba was used in form of Ghanvati and compared with tab. Diclofenac sodium ${ }^{5}$.

Various experimental and clinical studies have been done so far to assess the analgesic and anti-inflammatory action of some medicinal plants and indigenous compounds. In the present research work an indigenous drug Kadamba (Anthocephalus indicus) was selected to evaluate for its efficacy as an antiinflammatory and analgesic, in the post-operative pain management under Lumber subarachnoid block.

\section{Collection and preparation of Drug}

The stem bark of Kadamba (Anthocephalus indicus) was collected from Ayurvedic Pharmacy, Institute of Medical
Sciences, Banaras Hindu University, Varanasi and after confirming its validity by Dravya Guna department. The Ghansatva of Kadamba bark was prepared in ayurvedic pharmacy, I.M.S., BHU, Varanasi with the standard preparatory methods as mentioned in the texts of Ayurveda. For present research work drug was formulated in the form of vati of $500 \mathrm{mg}$.

\section{Dose of Kadamba Ghanvati}

Ghanvati 1 gm (2 tablets) at 10 p.m. of preoperative night and 1 gm ( 2 tablets) 90 min before the operation was the standard dose regime for the trial group.

\section{Disintegration Time}

The disintegration time of the prepared tablet at $37^{\circ} \mathrm{C}$ of water was observed in the disintegration time machine. The time required for complete disintegration of tablet was found 34 minutes. The Kadamba Ghanvati was expected to dissolve in the stomach within their disintegration time.

\section{Selection of the Patients}

40 patients of either sex of A.S.A (American Society of Anesthesiologists) grade I and II undergoing, herniotomy with herniorrhaphy, hernioplasty, B.L.T.L., scrotoplasty, penoplasty, Primary threading, hemorrhoidectomy, appendectomy, hysterectomy, prostatectomy and Pilonidal sinus were selected from the Sangyaharan OPD, S.S. Hospital, Institute of Medical Sciences, Banaras Hindu University, Varanasi. All patients of both groups were to undergo Lumber-Subarachnoid block (LSAB). The patients with deformities of spinal cord, 
neurological and mental disturbances, hepatic diseases and renal diseases, cardiovascular diseases, hypersensitive to local anaesthetic, Diclofenac sodium and local infection were excluded. The study was conducted after proper written consent of individual patients explaining the methodology and aim of the study. Ethical approval was taken from the Institute ethical committee (Dean/2006-07/858, issued on 22.11.2006)

\section{Grouping of the Patients}

The selected 40 patients were randomly divided into two equal and identical groups i.e. group- I (control) and group-II (Trial) and were planned surgical procedures under spinal anesthesia.

\begin{tabular}{|c|c|cl|}
\hline Groups & No. of Patients & \multicolumn{1}{c|}{ Premedication } \\
\hline $\begin{array}{c}\text { Group } \\
\text { I } \\
\text { (Control) }\end{array}$ & 20 & 1. & $\begin{array}{l}\text { Tab. Diclofenac } 50 \mathrm{mg} \text { at } 10 \mathrm{pm} \text { (previous night) and one hour before operation with an } \\
\text { ounce of plain water orally. } \\
\text { Inj. Glycopyrrolate } 0.2 \mathrm{mg} \text { I.M. 1 hour before the induction anesthesia }\end{array}$ \\
\hline $\begin{array}{c}\text { Group } \\
\text { II } \\
\text { (Trial) }\end{array}$ & 20 & 1. & $\begin{array}{l}\text { Two tablets of Kadamba Ghanvati (500 mg each) at } 10.00 \text { pm (previous night) and one } \\
\text { hours before operation with an ounce of plain water orally } \\
\text { Inj. Glycopyrrolate } 0.2 \mathrm{mg} \text { IM 1 hour before the induction of anesthesia }\end{array}$ \\
\hline
\end{tabular}

\section{Preoperative Preparation and Premeditation}

All the patients were assessed thoroughly, and consent was taken about the proposed research work. Their age (years), weight $(\mathrm{kg})$, and vital status viz. pulse rate, blood pressure, respiratory rate, oxygen-saturation, end tidal $\mathrm{CO}_{2}$ and oral temperature were recorded. General condition, physiological and psychological conditions were also recorded. The relevant routine investigations, which are essential prerequisite for the conduct of anesthesia, were evaluated and after complete satisfaction the grouping was done.

One hour after the scheduled medication, injection glycopyrrolate $0.2 \mathrm{mg}$ was given by intramuscular route to the patient of both the groups, using uniformly the $24 \mathrm{G}$ needle. Sixty minutes after premedication with injection glycopyrrolate, the patients were reevaluated thoroughly regarding their vital signs, physiological and psychological conditions etc. Observations were recorded on the standard proforma for the study.

A patent intravenous line with Ringer lactate solution was maintained by identical size $18 \mathrm{G}$ intravenous cannula. After adequate preloading, the patients of were transferred to operation table. The induction of anesthesia was done by lumber subarachnoid block (LSAB) in lateral position (Knee-chest position) keeping their head on the pillow.
Now proper antiseptic dressing and draping of the Lumber area was done. Lumber puncture was done in all the cases of group- A by using $25 \mathrm{G}$ spinal needle by midline approach. After ensuring free flow of CSF at the rate of $1 \mathrm{drop} / \mathrm{sec}$ inj. bupivacaine $0.5 \%$ (heavy) $3 \mathrm{ml}$ was administered with bevel of needles maintained in cephalic position, and needle was withdrawn, and the area of skin prick was covered with sterile gauze piece. The patients were asked to change their posture to supine position with the help of assistant and adequate subarachnoid block was identified by absence of pinprick and touch sensation in operative area. ${ }^{6}$

\section{Statistical Analysis}

All the data collected viz. - Age, weight, height, blood pressure, pulse rate, respiratory rate, oral temperature, oxygen saturation, end tidal carbon dioxide, total surgical time, total duration of anesthesia, desirable and undesirable effect. First analgesic dose requirement time and post anesthetic sequel etc., were also recorded in a properly planned manner with the help of statistician on a master chart. The different statistical values as advocated for comparison e.g. mean, standard deviation (SD), applying unpaired t-test, $\mathrm{t}$-value, standard error, $\mathrm{p}$-value, $\mathrm{z}$-value, using percentage of incidence and degree of freedom etc., were calculated under the guidance of expert statistician. The observations were noted and were presented in graphical way.

\section{OBSERVATION AND RESULT}

Table 1: Age, weight and Height

\begin{tabular}{|c|c|c|c|c|}
\hline \multicolumn{2}{|l|}{ Group } & $\begin{array}{l}\text { Age (years) } \\
\text { Mean } \pm \text { SD }\end{array}$ & $\begin{array}{l}\text { Weight (Kg) } \\
\text { Mean } \pm \text { SD }\end{array}$ & $\begin{array}{c}\text { Height }(\mathbf{c m}) \\
\text { Mean } \pm \text { SD }\end{array}$ \\
\hline \multicolumn{2}{|c|}{ Group -I (Control) } & $41.75 \pm 12.63$ & $57.55 \pm 7.02$ & $164.80 \pm 3.82$ \\
\hline \multicolumn{2}{|c|}{ Group -II (Trial) } & $38.80 \pm 15.30$ & $54.50 \pm 6.04$ & $164.60 \pm 4.76$ \\
\hline \multirow{2}{*}{$\begin{array}{l}\text { Comparison between groups } \\
\text { unpaired ' } t \text { ' test }\end{array}$} & T value & $\mathrm{t}=0.66$ & $\mathrm{t}=1.47$ & $\mathrm{t}=0.15$ \\
\hline & $\mathrm{p}$-value & $p>0.05$ & $\mathrm{P}>0.05$ & $\mathrm{P}>0.05$ \\
\hline \multicolumn{2}{|l|}{ Remark } & NS & NS & NS \\
\hline
\end{tabular}

It is obvious from the above table that mean age, weight and height are statistically comparable and identical $(p>0.05)$ in the patients of both the groups. 


\section{Effect on Respiratory rate}

Table 2A: The statistical comparison of mean respiratory rate per minute before premedication (A), after premedication (B), during subsequent anesthesia $(C)$ and after recovery from anesthesia $(D)$ between the two groups at corresponding time by applying student t-test and p-values and remarks are as follows

\begin{tabular}{|c|c|c|c|c|c|}
\hline \multirow{2}{*}{\multicolumn{2}{|c|}{ Group }} & \multicolumn{4}{|c|}{ Mean Respiratory Rate/min; (Mean ${ }_{ \pm}$SD) } \\
\hline & & $\begin{array}{c}\text { Before } \\
\text { premedication (A) }\end{array}$ & $\begin{array}{c}\text { After } \\
\text { premedication (B) }\end{array}$ & $\begin{array}{c}\text { During subsequent } \\
\text { anesthesia (C) }\end{array}$ & $\begin{array}{c}\text { After recovery from } \\
\text { anesthesia (D) }\end{array}$ \\
\hline \multicolumn{2}{|l|}{ Group-I (Control) } & $16.75 \pm 2.05$ & $16.75 \pm 1.62$ & $17.50 \pm 2.14$ & $16.75 \pm 1.42$ \\
\hline \multicolumn{2}{|l|}{ Group-II (Trial) } & $16.90 \pm 2.38$ & $16.60 \pm 1.96$ & $17.40 \pm 2.26$ & $16.70 \pm 1.63$ \\
\hline \multirow{2}{*}{$\begin{array}{l}\text { Comparison between } \\
\text { groups unpaired ' } t \text { ' test }\end{array}$} & $\mathrm{t}$ value & $\mathrm{t}=-0.21$ & $\mathrm{t}=0.26$ & $\mathrm{t}=0.14$ & $\mathrm{t}=0.10$ \\
\hline & p-value & $\mathrm{p}>0.05$ & $\mathrm{p}>0.05$ & $\mathrm{p}>0.05$ & $\mathrm{P}>0.05$ \\
\hline \multicolumn{2}{|l|}{ Remark } & NS & NS & NS & NS \\
\hline
\end{tabular}

Table $2 \mathrm{~A}$ shows that mean respiratory rate/min in group - I at all the four level before premedication (A), after premedication (B) during subsequent anesthesia $(\mathrm{C})$ and after recovery from anesthesia (D) is $16.75 \pm 2.05,16.75 \pm 1.62$ and $17.50 \pm 2.14$, $16.75 \pm 1.42$ respectively, while in group - II it is $16.90 \pm 2.38$,
$16.60 \pm 1.96$ and $17.40 \pm 2.26,16.70 \pm 1.63$, respectively.

From Table 2A, it is observed that difference of mean respiratory rate per minute when compared in between group - I and group II at corresponding four different timings; it is statistically insignificant and identical.

Table 2B: The statistical comparison of mean respiratory rate per minute within both groups before premedication (A), after premedication (B), during subsequent anesthesia $(C)$ and after recovery from anesthesia (D), by mean \pm SD, paired t-test, p-values and remark are as follows

\begin{tabular}{|c|c|c|c|c|c|c|}
\hline \multirow{2}{*}{$\begin{array}{c}\text { Comparison within } \\
\text { the groups }\end{array}$} & \multicolumn{2}{|c|}{ Group I (Control) } & \multicolumn{3}{c|}{ Group II (Trial) } \\
\cline { 2 - 7 } & Mean \pm SD & $\begin{array}{c}\text { t-value } \\
\text { p-value }\end{array}$ & Remark & Mean \pm SD & $\begin{array}{l}\text { t-value } \\
\text { p-value }\end{array}$ & Remark \\
\hline A vs. B & $0.00 \pm 1.55$ & $\begin{array}{l}\mathrm{t}=0.00 \\
\mathrm{p}>0.05\end{array}$ & $\mathrm{NS}$ & $0.30 \pm 2.27$ & $\begin{array}{l}\mathrm{t}=0.59 \\
\mathrm{p}>0.05\end{array}$ & $\mathrm{NS}$ \\
\hline A vs. C & $-0.75 \pm 2.51$ & $\begin{array}{l}\mathrm{t}=-1.34 \\
\mathrm{p}>0.05\end{array}$ & $\mathrm{NS}$ & $-0.50 \pm 3.17$ & $\begin{array}{l}\mathrm{t}=-0.71 \\
\mathrm{p}>0.05\end{array}$ & $\mathrm{NS}$ \\
\hline A vs. D & $0.00 \pm 1.52$ & $\begin{array}{l}\mathrm{t}=0.00 \\
\mathrm{p}>0.05\end{array}$ & $\mathrm{NS}$ & $0.20 \pm 3.03$ & $\begin{array}{l}\mathrm{t}=0.29 \\
\mathrm{p}>0.05\end{array}$ & $\mathrm{NS}$ \\
\hline
\end{tabular}

From Table 2B, it is observed that changes in respiratory rate are insignificant in both groups at the levels of before premedication vs. after premedication, before premedication vs. during subsequent anesthesia and before premedication vs. after recovery from anesthesia

\section{Effect on oxygen saturation}

Table 3A: The statistical comparison of difference in SPO2 percentage between the two groups at corresponding time i.e. before premedication (A), after premedication (B), during subsequent anesthesia (C), after recovery from anesthesia (D), by applying student t-test, p-values and remarks are as follows

\begin{tabular}{|c|c|c|c|c|c|}
\hline \multirow{2}{*}{\multicolumn{2}{|c|}{ Group }} & \multicolumn{4}{|c|}{$\begin{array}{c}\text { Mean oxygen saturation (\%) } \\
(\text { Mean 士 SD) }\end{array}$} \\
\hline & & $\begin{array}{c}\text { Before } \\
\text { premedication }(\mathrm{A})\end{array}$ & $\begin{array}{c}\text { After } \\
\text { premedication (B) }\end{array}$ & $\begin{array}{c}\text { During subsequent } \\
\text { anesthesia }(\mathrm{C})\end{array}$ & $\begin{array}{c}\text { After recovery from } \\
\text { anesthesia (D) }\end{array}$ \\
\hline \multicolumn{2}{|c|}{ Group-I (Control) } & $99.00 \pm 1.17$ & $98.95 \pm 0.94$ & $99.00 \pm 1.03$ & $98.85 \pm 1.14$ \\
\hline \multicolumn{2}{|c|}{ Group-II (Trial) } & $98.90 \pm 0.79$ & $99.10 \pm 0.79$ & $99.25 \pm 0.79$ & $99.20 \pm 0.83$ \\
\hline \multirow{2}{*}{$\begin{array}{l}\text { Comparison between } \\
\text { group unpaired ' } t \text { ' test }\end{array}$} & $\mathrm{t}$ value & $\mathrm{t}=0.32$ & $\mathrm{t}=-0.55$ & $\mathrm{t}=-0.86$ & $\mathrm{t}=-1.11$ \\
\hline & p-value & $\mathrm{p}>0.05$ & $\mathrm{P}>0.05$ & $\mathrm{p}>0.05$ & $\mathrm{P}>0.05$ \\
\hline \multicolumn{2}{|l|}{ Remark } & NS & NS & NS & NS \\
\hline
\end{tabular}

From Table 3A, it can be observed that mean SPO2 percentage in group - I, before and after premedication was $99.00 \pm 1.17$ and $98.95 \pm 0.94$, respectively while in group - II, it was $98.90 \pm 0.79$ and 99.10 \pm 0.79 , respectively. Again, mean SPO2 percentage in group - I during subsequent anesthesia and after recovery from anesthesia was $99.00 \pm 1.03$ and $98.85 \pm 1.14$ while in group - II it was $99.25 \pm 0.79$ and $99.20 \pm 0.83$ respectively.

From Table 3A, it is observed that difference of mean SPO2 percentage when compared between group - I and group - II at corresponding four different timings it is insignificant. 
Table 3B: Statistical comparison of difference in the mean SPO2 percentage before premedication (A), after premedication (B), during subsequent anesthesia $(C)$, and after recovery from anesthesia $(D)$, within the groups by applying paired t-test, p-values and remarks are as follows

\begin{tabular}{|c|c|c|c|c|c|c|}
\hline \multirow{2}{*}{$\begin{array}{c}\text { Comparison within the } \\
\text { groups }\end{array}$} & \multicolumn{3}{|c|}{ Group A I (Control) } & \multicolumn{3}{|c|}{ Group A II (Trial) } \\
\hline & Mean \pm SD & $\begin{array}{l}\text { t-value } \\
\text { p-value }\end{array}$ & Remark & Mean \pm SD & $\begin{array}{l}\text { t-value } \\
\text { p-value }\end{array}$ & Remark \\
\hline A vs. B & $0.05 \pm 0.88$ & $\begin{array}{l}\mathrm{t}=0.25 \\
\mathrm{p}>0.05\end{array}$ & NS & $-0.20 \pm 1.10$ & $\begin{array}{l}\mathrm{t}=-0.81 \\
\mathrm{p}>0.05\end{array}$ & NS \\
\hline A vs. C & $0.00 \pm 1.33$ & $\begin{array}{l}\mathrm{t}=0.00 \\
\mathrm{p}>0.05\end{array}$ & NS & $0.35 \pm 1.08$ & $\begin{array}{l}t=-1.44 \\
p>0.05\end{array}$ & NS \\
\hline A vs. D & $0.15 \pm 1.46$ & $\begin{array}{l}t=0.46 \\
p>0.05\end{array}$ & NS & $-0.30 \pm 1.12$ & $\begin{array}{l}\mathrm{t}=-1.19 \\
\mathrm{p}>0.05\end{array}$ & NS \\
\hline
\end{tabular}

From Table 3B it is observed that difference of $\mathrm{SPO}_{2}$ percentage at the level of before premedication and after premedication is insignificant in group - I and also in group - II and difference of mean $\mathrm{SPO}_{2}$ before premedication, during subsequent anesthesia and after recovery from of anesthesia is insignificant in both groups.

\section{Effect on end tidal carbon dioxide $\left(\mathrm{ETCO}_{2}\right)$}

Table 4A: The statistical comparison of difference of mean $\mathrm{ETCO}_{2}$ in $\mathbf{m m H g}$, between the two groups at corresponding time i.e. before premedication (A), after premedication (B), during subsequent anesthesia (C), after recovery from anesthesia (D), by applying student t-test, p-values and remarks are as follows

\begin{tabular}{|c|c|c|c|c|c|}
\hline \multirow{2}{*}{\multicolumn{2}{|c|}{ Group }} & \multicolumn{4}{|c|}{ Mean ETCO2 (mmHg); (Mean $\pm \mathrm{SD})$} \\
\hline & & $\begin{array}{c}\text { Before premedication } \\
\text { (A) }\end{array}$ & $\begin{array}{c}\text { After premedication } \\
\text { (B) }\end{array}$ & $\begin{array}{l}\text { During subsequent } \\
\text { anesthesia (C) }\end{array}$ & $\begin{array}{c}\text { After recovery from } \\
\text { anesthesia (D) }\end{array}$ \\
\hline \multicolumn{2}{|c|}{ Group -I (Control) } & $30.70 \pm 2.27$ & $30.70 \pm 1.63$ & $30.70 \pm 1.87$ & $31.10 \pm 1.77$ \\
\hline \multicolumn{2}{|c|}{ Group -II (Trial) } & $30.80 \pm 1.51$ & $30.90 \pm 1.37$ & $30.60 \pm 3.25$ & $30.90 \pm 1.89$ \\
\hline \multirow{2}{*}{$\begin{array}{c}\text { Comparison } \\
\text { between groups } \\
\text { unpaired ' } t \text { ' test }\end{array}$} & $\mathrm{T}$ value & $\mathrm{t}=-0.16$ & $\mathrm{t}=-0.39$ & $\mathrm{t}=0.12$ & $\mathrm{t}=0.35$ \\
\hline & p-value & $\mathrm{p}>0.05$ & $\mathrm{p}>0.05$ & $\mathrm{p}>0.05$ & $\mathrm{P}>0.05$ \\
\hline \multicolumn{2}{|c|}{ Remark } & NS & NS & NS & NS \\
\hline
\end{tabular}

From Table 4A, it can be observed that mean $\mathrm{ETCO}_{2}(\mathrm{mmHg})$ in group-I, before and after premedication was $30.70 \pm 2.27$ and $30.70 \pm 1.63$, respectively while in group - II, it was $30.80 \pm 1.51$ and $30.90 \pm 1.37$ respectively. Again, mean $\mathrm{ETCO}_{2}(\mathrm{mmHg})$ in group - I during subsequent anesthesia and after recovery from

Table 4B: Statistical comparison of difference in the mean $\mathrm{ETCO}_{2}(\mathrm{mmHg})$ before premedication $(\mathrm{A})$, after premedication $(\mathrm{B})$, during subsequent anesthesia $(C)$, and after recovery from anesthesia $(D)$, within the groups by applying paired t-test, p-values and remarks are as follows

\begin{tabular}{|c|c|c|c|c|c|c|}
\hline \multirow{2}{*}{$\begin{array}{c}\text { Comparison within } \\
\text { the groups }\end{array}$} & \multicolumn{3}{|c|}{ Group -I ( Control ) } & \multicolumn{3}{|c|}{ Group - II ( Trial ) } \\
\hline & Mean \pm SD & $\begin{array}{l}\text { t-value } \\
\text { p-value }\end{array}$ & Remark & Mean \pm SD & $\begin{array}{l}\text { t-value } \\
\text { p-value }\end{array}$ & Remark \\
\hline A vs. B & $0.00 \pm 1.71$ & $\begin{array}{l}\mathrm{t}=0.00 \\
\mathrm{p}>0.05\end{array}$ & NS & $-0.10 \pm 1.88$ & $\begin{array}{l}\mathrm{t}=-0.24 \\
\mathrm{p}>0.05\end{array}$ & NS \\
\hline A vs. C & $0.00 \pm 2.24$ & $\begin{array}{l}\mathrm{t}=0.00 \\
\mathrm{p}>0.05\end{array}$ & NS & $0.20 \pm 3.66$ & $\begin{array}{l}\mathrm{t}=0.24 \\
\mathrm{p}>0.05\end{array}$ & NS \\
\hline A vs. D & $-0.40 \pm 2.94$ & $\begin{array}{l}t=-0.61 \\
p>0.05\end{array}$ & NS & $0.10 \pm 2.93$ & $\begin{array}{l}\mathrm{t}=-0.15 \\
\mathrm{p}>0.05\end{array}$ & NS \\
\hline
\end{tabular}

From Table 4B, it is observed that difference of mean $\mathrm{ETCO}_{2}(\mathrm{mmHg})$, at the level of before premedication and after premedication and before premedication, during subsequent anesthesia and before premedication and after recovery from anesthesia is insignificant in group - I and group - II.

\section{DISCUSSION}

The patients of all groups had similar age, height, weight. It was observed that changes in Respiratory rate, $\mathrm{SpO} 2, \mathrm{EtCO} 2$ between the groups at different level was insignificant and within the group at different level was almost similar. So this can be explained that there was no alteration in respiratory system of patients of all the groups. It means that the trial and control drugs do not produce any unwanted effect on respiratory system. Kadamba is described as vednasthapak dravya in Ayurvedic texts and it can be used in inflammatory painful condition without any untoward effects and post anesthesia sequels. anesthesia was $30.70 \pm 1.87$ and $31.10 \pm 1.77$ while in group - II it was $30.60 \pm 3.25$ and $30.90 \pm 1.89$ respectively.

From Table 4A, it is observed that difference of mean $\mathrm{ETCO}_{2}$ $(\mathrm{mmHg})$ when compared in between group - I and group - II at corresponding four different timings it is insignificant. 
these observations suggest that there was no any serious untoward effect of the both premedicants (control and trial) on respiratory system which can jeopardize to life of the patients.

\section{REFERENCES}

1 Sharma P.V. - Classical usage of medicinal plant, Chaukhamba Prakashana; 1996.

2 Sharma P.V. Dravyaguna vigyana Parts II, Chaukhambha Prakashana, Varanasi; 1975.

3 Pande S.B. Evaluation of Aswagandha as Pre anesthetic agent. Ph. D.Ay. Thesis, IMS, BHU, Varanasi; 1977.

4 Pande D.N. Poorva karama in relation to Anesthesia, M. D.Ay. Thesis, IMS, BHU, Varanasi; 1986.

5 Roy A.K. Role of Shigrughanasatva under Sarvadaihiksangyaharan: A Clinical Study. M. S.Ay. Sangyaharan Thesis, I.M.S., B.H.U., Varanasi; 2005.

6 Sah G. S. Study of Parijat in Post-Operative Pain under Subarachnoid Block; 1998.
7 Vyas SN and Shukla CP. A clinical study on the effect of Shuddha Guggulu in rheumatoid arthritis. Rheumatism 1987; 23: 15 .

8 Chopra R.N. et al. Indigenous Drug of India. U.N. Dhar and Sons Pvt. Ltd., 15, Bankim Chatterjee Street, Calcutta $2^{\text {nd }} E d$; 1958.

9 Chopra R.N. et al. Supplement to glossary of Indian medicinal Plant Council of Science and Ind. Res., New Delhi; 1968.

10 Pandey K.K. Role of Medhya Dravyas in Snagyaharan Ph.D. Thesis, IMS, BHU, Varanasi; 1990.

11 Pandey P.S. et al Studies on an indigenous compound (Nirgundi, Erandmool and Bhringaraja) as an analgesic. M. S.Ay. Sangyaharan thesis. IMS, BHU, Varanasi; 1997.

\section{Cite this article as:}

Vimal Kumar et al. A Clinical Evaluation of Kadamba (Anthocephalus indicus) on Respiratory System under Spinal Anesthesia. Int. J. Res. Ayurveda Pharm. 2020;11(2):38-42 http://dx.doi.org/10.7897/2277-4343.110227

Disclaimer: IJRAP is solely owned by Moksha Publishing House - A non-profit publishing house, dedicated to publishing quality research, while every effort has been taken to verify the accuracy of the content published in our Journal. IJRAP cannot accept any responsibility or liability for the site content and articles published. The views expressed in articles by our contributing authors are not necessarily those of IJRAP editor or editorial board members. 